Andrew Walker, UC Davis geneticist who developed these rootstocks over 15 years. "It's either use these or other resistant rootstocks or don't grow grapes in areas with nematode buildup."

Released in April 2008, these rootstocks were derived from multiple parents that each resist different kinds of nematodes, including dagger, lesion and root-knot. "We bred them to be as resistant as possible," Walker says. Even so, he expects that these pests may eventually adapt. By rotating among the five types, however, growers should be guaranteed a long period free of nematode problems.

Walker is also developing wine grapes that resist powdery mildew and Pierce's disease, a fatal bacterial illness spread by sharpshooters. These projects entail breeding commercially grown wine grapes (Vitis vinifera), which are native to the Mediterranean, with disease-resistant wild North American grapes. To get as close to wine grapes as possible, disease-resistant hybrids are selected and then repeatedly crossed back to pure wine grapes. This backcrossing increases the ratio of wine grape-to-wild grape in the successive hybrids while retaining their disease resistance. The powdery mildew project is still in early stages, while the Pierce's disease project has made strong advances. "We have good fruit quality and Pierce's disease re- sistance," Walker says. "After one more backcross, we'll be at $96 \%$ Vitis vinifera and we'll test those by evaluating for wine quality."

In other research, UC Berkeley plant pathologist Steven Lindow has discovered a signaling system involving the secretion of a small molecule produced by Xylella fastidiosa, the cause of Pierce's disease. This molecule is involved in the suppression of Xylella virulence when cells become abundant in the plant. Artificially increasing the abundance of this signal molecule in various ways, including the use of plants that have been genetically engineered to produce it, has led to the suppression of virulence of the pathogen and Pierce's disease control. Extensive greenhouse tests are under way, but field studies will not commence before next year at the earliest.

As scientific advances occur and are made available, even more growers will be encouraged to adopt sustainable practices. "The work by UC has been critical to our success," Ross says.

- Robin Meadows

\title{
Nest boxes can attract wildlife to vineyards
}

$P_{i}^{i}$ lacing nest boxes for songbirds, owls and bats in and around vineyards can contribute to the sustainable management of pests and help mitigate oak-woodland habitat losses, according to a new booklet published by the UC Division of Agriculture and Natural Resources, "Songbird, Bat and Owl Boxes: Vineyard Management with an Eye toward Wildlife."

"Nest boxes are readily accepted by a number of bird and bat species and provide places for these animals to roost and nest. Used properly, they can help maintain biodiversity in vineyard landscapes," says Emily Heaton, co-author of the 51-page booklet with Rachael Long, Chuck Ingels and Tom Hoffman.

The booklet is illustrated with color images and provides information on the rationale for placing nest boxes and bat houses in vineyards; which species may be attracted to them, as well as feeding and nesting behavior; detailed plans for building, placing and monitoring bird boxes and bat houses; and references and resources.

"The growers that I worked with really enjoyed seeing birds in the vineyards," says Heaton, a UC Berkeley doctoral student who has conducted research on songbird boxes in vineyards. "Plus the birds are in there eating insects, and that may have some beneficial effect in terms of pest control."

Many species native to woodlands - such as some songbirds, owls and bats use cavities in oak trees for roosting or nesting, and they lose habitat when trees are cleared for new agricultural plantings. Vineyard development expanded rapidly during the 1990s, especially on the Central Coast and North Coast, says Bill Tietje, technical editor of the booklet. "Unlike most row crops, soil characteristics and topography did not completely restrict some new vineyard development from areas formerly classified as oak woodland."

"There was a lot of public concern about impacts on views and biodiversity," Tietje continues, "and growers would like to demonstrate that they are

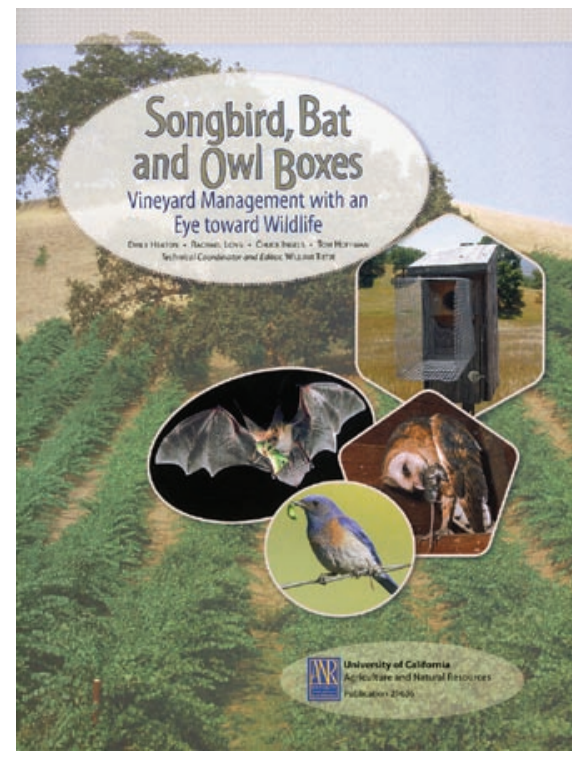

ANR Pub 21636 can be ordered at anrcatalog.ucdavis. edu. 


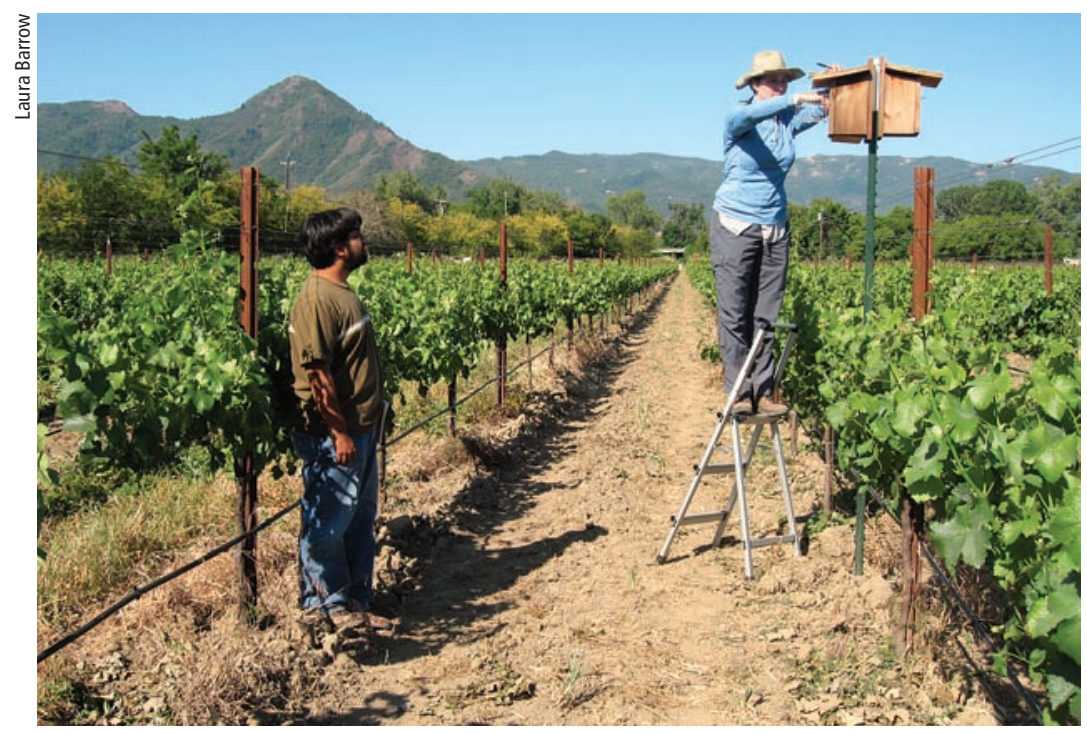

At Dooley Creek in Hopland, UC Santa Cruz Ph.D. candidate Julie Jedlicka (right) and field assistant Matthew Poonamallee monitor nest boxes placed in a vineyard.

practicing good conservation." For example, growers who participate in sustainability assessments such as the Lodi Winegrower's Workbook receive credit for placing nest boxes for birds of prey (see pages 133 and 142).

\section{Pros and cons}

Heaton monitored 288 songbird boxes placed in and around Napa and Sonoma county vineyards over 2 years. At least $85 \%$ of these boxes were used for nesting during the study. Western bluebirds and tree swallows were the most common occupants, plus five other native species. Overall, $54 \%$ of nests fledged one or more young (Heaton, unpublished data). However, nest success rates were highly variable between sites, ranging from $17 \%$ to $89 \%$. "Predation was the main cause of nest failure," Heaton says. "Raccoons or domestic cats wiped out a significant number of nests at some sites."

Heaton strongly recommends that boxes be outfitted with predator guards and that growers monitor their boxes to make sure they are not doing more harm than good to songbirds.

Tietje and other scientists point out that studies have not been conducted to confirm whether the widespread placement of nest boxes can boost or stabilize local populations of native species; nor does existing research support the idea that wildlife can effectively reduce pest insects and rodents in vineyards.

“These practices can play an important role in an integrated pest management program, but it would be wrong, for example, to say that owl nest boxes can control rodent populations," Tietje says. "Rather, barn owls can help by extending naturally low cycles in rodent populations and thereby reduce the need for chemical pest control."
Many unanswered questions remain that, if answered, would assist both growers and biodiversity conservation. "Although some cavity-nesting birds, especially western bluebirds, readily use and fledge young from nest boxes in vineyards, what happens to the fledged young?" Tietje says. "Are the vineyards functioning as an 'ecological trap,' and is the trap sprung after young fledge from the boxes, perhaps due to increased predation or altered food resources in the vineyard?" A few studies are under way in California that will help to develop management guidelines for nest and bat boxes.

\section{Research on vineyard wildlife}

Julie Jedlicka, a Ph.D. candidate in environmental studies at UC Santa Cruz, is studying the use of nest boxes as a biocontrol agent and conservation tool. She points out that this type of research is not new: Between 1885 and 1940, the U.S. Department of Agriculture's “Department of Economic Ornithology" extensively studied the use of insecteating birds to control pests in agriculture. But when chemical pest-control methods began to take precedence, Jedlicka says, the department was disbanded.

Jedlicka's research in Sonoma and Mendocino counties is examining the breeding success and diets of songbirds that use vineyard and riparian nest boxes. In addition, Jedlicka has placed large mesh exclosures in vineyards to monitor insect levels when birds and bats don't have access to grapevines; and to mimic an outbreak of Lepidoptera, she is pinning pupa to the undersides of grape leaves to determine the extent of consumption by birds. Finally, she is mist-netting in the vineyards to monitor and band insectivorous birds and collect fecal samples, which are being tested for the exoskeletons of vineyard pest insects.

"I am looking at whether nest boxes are boosting bird populations, and whether the birds are eating common vineyard pests such as grape leafhoppers and blue-green sharpshooters," Jedlicka says.

Long, a UC Cooperative Extension farm advisor in Yolo, Solano and Sacramento counties, is in the midst of a study on whether bats are feeding on orchard pests. The bats are being captured at night in orchards and held for a short time until they defecate. The guano samples are then analyzed for DNA evidence of codling moth, an important pest of orchard crops.

So far, the results show that nocturnal bats do eat codling moths, which fly at night. "Bats alone are not going to control these pest insects," says Long, who wrote the booklet's chapter on bat houses. "But they are one of our many beneficial natural enemies that contribute to biological control."

- Janet Byron 